\title{
Biologic monotherapy versus combination therapy with immunomodulators in the induction and maintenance of remission of Crohn's disease and ulcerative colitis
}

\author{
Jana G. Hashasha*, Carla G. Abou Fadel ${ }^{b *}$, Hussein H. Rimmania ${ }^{\text {, Ala I. Sharara }}{ }^{a}$ \\ American University of Beirut Medical Center, Beirut; Bellevue Medical Center, Mansourieh, Lebanon
}

\begin{abstract}
Despite current guidelines, the optimal treatment of patients with inflammatory bowel disease (IBD) remains challenging. The available medications are not without risk and there is not a single correct treatment regimen for every patient. Personalizing treatment and selecting the most appropriate therapy is crucial for optimal response, remission, quality of life, and healthcare utilization. Biologics, especially anti-tumor necrosis factor- $\alpha$ medications, are widely used in the induction and maintenance of disease remission in patients with IBD. Similarly, immunomodulators, including thiopurines and methotrexate, are traditionally popular for the maintenance of remission. In this manuscript, we review the use of biologic monotherapy vs. combination therapy with immunomodulators for the treatment of ulcerative colitis and Crohn's disease. We examine overall remission, immunogenicity and adverse effects, mainly serious infections and malignancy, in an effort to help guide treatment decisions and weigh the risks and benefits of biologic monotherapy vs. combination therapy.
\end{abstract}

Keywords Inflammatory bowel disease, Crohn's disease, ulcerative colitis, thiopurines, azathioprine

Ann Gastroenterol 2021; 34 (1): 1-13

\section{Introduction}

Inflammatory bowel disease (IBD), which includes ulcerative colitis (UC) and Crohn's disease (CD), is a general term describing chronic inflammatory diseases that affect the gastrointestinal tract. The incidence of IBD has been on the rise worldwide. IBD is estimated to affect 1.6 million USA residents and up to 3.7 million European residents [1-3]. IBD affects patients of all age groups, but has 2 peaks: a main peak between ages 15 and 25 years and another peak in the fifth to

${ }^{a}$ Division of Gastroenterology, Department of Internal Medicine, American University of Beirut Medical Center, Beirut (Jana G. Hashash, Hussein H. Rimmani, Ala I. Sharara); ${ }^{b}$ Division of Gastroenterology, Bellevue Medical Center, Mansourieh (Carla G. Abou Fadel), Lebanon

*Indicates shared first authorship

Conflict of Interest: None

Correspondence to: Ala I. Sharara, MD, FACG, AGAF, FRCP, Professor, Division of Gastroenterology, American University of Beirut Medical Center, P.O. Box 11-0236/16-B, Beirut, Lebanon,

e-mail: ala.sharara@aub.edu.lb

Received 16 January 2021; accepted 12 March 2021; published online 14 June 2021

DOI: https://doi.org/10.20524/aog.2021.0645 seventh decade of life [4-7]. Patients with IBD tend to have a diminished quality of life, especially those with active disease. The ultimate goal of treatment is to induce disease remission and to maintain it.

To date, IBD has no cure and current treatments are associated with a number of side-effects. Available medications for the treatment of IBD include corticosteroids, 5-aminosalycilic acid (5-ASA) drugs, immunomodulators, biologic agents and small molecules. Corticosteroids are commonly used in symptomatic patients with moderate-to-severe UC and $\mathrm{CD}$ to induce remission. They are not generally used for the maintenance of remission, because of their side-effect profile and lack of effectiveness when used for prolonged periods of time. Immunomodulator drugs include methotrexate and the thiopurines, azathioprine, and 6-mercaptopurine. Thiopurines have a slow onset of action with clinical remission observed at 12-17 weeks [8], compared to 6-8 weeks for methotrexate [9], which explains the use of the latter as an induction agent in $\mathrm{CD}$. They are steroid-sparing drugs and are commonly used to maintain remission after induction with corticosteroids.

Immunomodulators are also commonly used in combination with biologic medications for a synergistic effect to achieve and maintain disease remission. Additionally, combination therapy is used to decrease the risk of immunogenicity to the biologic agent. This results in prolongation of the drug's life in addition to higher serum drug levels $[10,11]$. Biologics include anti-tumor necrosis factor- $\alpha$ (anti-TNF- $\alpha$ ) drugs 
such as infliximab (chimeric anti-TNF- $\alpha$ ), adalimumab (a fully human monoclonal anti-TNF- $\alpha$ ), certolizumab pegol (a human monoclonal anti-TNF- $\alpha$ ), and golimumab. Biologics also include anti-integrin monoclonal antibodies, such as vedolizumab and natalizumab, as well as the anti-interleukin (IL)-12/IL-23 antibody medication, ustekinumab. An oral drug, tofacitinib, acts by non-selectively inhibiting the Janus kinase enzyme and was recently approved for the treatment of moderate-to-severe UC [12].

For the management of $\mathrm{CD}$, the American Gastroenterological Association (AGA) guidelines currently recommend the use of anti-TNF- $\alpha$ drugs to induce remission in high-risk CD patients [13]. The AGA also suggests the use of anti-TNF- $\alpha$ combined with thiopurines over antiTNF- $\alpha$ monotherapy to induce remission [13]. The latter recommendation is supported with moderate-quality evidence and is a weak recommendation. As for the maintenance of remission in patients with moderate-to-severe $\mathrm{CD}$, the AGA strongly recommends using an anti-TNF- $\alpha$ drug over no anti-TNF- $\alpha$ to maintain a corticosteroid-induced or an anti-TNF- $\alpha$-induced remission [13]. This recommendation is supported by high-quality evidence. The AGA makes no recommendations for or against the use of combination therapy with an anti-TNF- $\alpha$ drug and a thiopurine vs. antiTNF- $\alpha$ drug monotherapy to maintain remission in these patients. This recommendation (or lack of recommendation) is backed up by low-quality evidence.

As for the management of UC, the AGA classifies patients as low- or high-risk based on their risk for colectomy [14]. High-risk patients tend to be young $(<40$ years of age), have extensive colitis, deep ulcers on colonoscopy, elevated C-reactive protein (CRP) and erythrocyte sedimentation rate, require steroids, and have a history of hospitalization, cytomegalovirus or Clostridioides difficile infections. High-risk patients can be treated as outpatients or inpatients, depending on their symptoms and how ill they are. These patients can be induced with corticosteroids and/or anti-TNF- $\alpha$ agents and then maintained on thiopurines or anti-TNF- $\alpha$ drugs with or without immunomodulators [14]. Thiopurines are either used to maintain corticosteroid-free remission, or in combination with biologics in particular to decrease the risk of immunogenicity [15]. There are no strong recommendations for the use of combination therapy over biologic monotherapy based on the AGA guidelines [14].

There are many studies investigating the pros and cons of using biologic monotherapy compared to combination therapy (biologic agent with immunomodulator) in the induction and maintenance of UC and CD remission. Factors that would favor monotherapy include safety, lower financial burden and better compliance. Studies that show comparable remission rates and comparable immunogenicity risk amongst patients receiving biologic monotherapy and combination therapy make the choice of combination therapy obsolete; however, other studies that show lower response rates and a high risk of immunogenicity with monotherapy make combination therapy more appealing, even in the presence of an increased risk of serious events. In this paper, we review the published data comparing the use of monotherapy with combination therapy in remission induction and maintenance therapy for adult UC and CD patients.

\section{CD}

Monoclonal anti-TNF- $\alpha$ drugs used in CD include infliximab, adalimumab and certolizumab pegol. These monoclonal antibodies are associated with remission rates of $35-80 \%$ [16], while a loss of response occurs in approximately $10-15 \%$ of patients annually [17].

The AGA guidelines are in agreement with the World Congress of Gastroenterology and recommend that combination therapy with infliximab and azathioprine is more effective than infliximab monotherapy at inducing CD remission $[13,18]$. The European Crohn's and Colitis Organization (ECCO) guidelines recommend the use of anti-TNF- $\alpha$ in the induction of remission for CD, and make a distinction between adalimumab and infliximab [19]. For induction with adalimumab, the recommendation is against the use of combination adalimumab and thiopurine compared to adalimumab monotherapy (weak recommendation), while combination therapy is recommended in patients being initiated on infliximab (strong recommendation) over infliximab monotherapy for moderate-to-severe CD [19]. For the maintenance of remission, if anti-TNF- $\alpha$ was used for induction it should be continued, with or without immunomodulators. More recently, ustekinumab and vedolizumab have been approved as first-line biologics in the induction and maintenance of remission of moderate-to-severe CD [19-21].

\section{Infliximab}

The Study of Biologic and Immunomodulator Naïve Patients in CD (SONIC) trial was one of the pioneer studies that evaluated the rates of induction of remission, comparing different medications used, amongst moderate-to-severe CD patients naïve to both immunomodulators and anti-TNF- $\alpha$ drugs [22]. In this randomized controlled trial, a total of $508 \mathrm{CD}$ patients with moderate-to-severe CD (mean disease duration 2.2-2.4 years) were randomized to receive either azathioprine monotherapy, infliximab monotherapy, or combination therapy with azathioprine and infliximab. This study showed that, at week 26 , combination therapy was more effective than either infliximab monotherapy or azathioprine monotherapy at inducing corticosteroid-free clinical remission. Similarly, a trend for higher rates of mucosal healing were achieved in patients receiving combination therapy compared to infliximab monotherapy $(\mathrm{P}=0.06)$ and significantly higher when compared to azathioprine monotherapy $(\mathrm{P}<0.001)$ [22]. These results from the SONIC trial demonstrated that patients with early moderate-to-severe $\mathrm{CD}$, naïve to both drugs, who received combination therapy (with infliximab and azathioprine) had a more favorable outcome compared to those receiving infliximab monotherapy or azathioprine monotherapy. This advantage is unclear in patients who have previously failed to 
respond to one of these medications. In support of the SONIC trial, an early study by D'Haens et al also showed that early combination therapy was superior to conventional therapy for the induction of clinical remission [23].

In the SONIC study, the benefits of combination therapy were still present at 1 year from initiation of the trial, although this study was not designed to evaluate maintenance of remission but was rather an induction trial with a long follow up. Post hoc analyses of the SONIC trial showed superiority of combination therapy in achieving composite measures of deep remission [24]. Hazlewood et al also demonstrated that initial combination therapy was superior to infliximab monotherapy in the maintenance of remission [25]. A small open-label randomized trial examined the effect of combination therapy (infliximab with immunomodulator) compared to infliximab monotherapy on the maintenance of remission of $\mathrm{CD}$ patients [26]. In this study, CD patients initially treated with combination therapy (infliximab/immunomodulator) for at least 6 months were then randomized to continuation of combination therapy vs. discontinuation of the immunomodulator. The results of this study showed that combination therapy was not superior to infliximab monotherapy in terms of disease relapse [26]. However, the study was underpowered. Additionally, it was noted that patients who continued on combination therapy had lower CRP levels and higher infliximab trough levels, which reflect remission and inactive disease, hinting that a longer follow-up study might have shown significant differences in outcome [26]. In a recent retrospective study, Drobne et al evaluated the withdrawal of immunomodulators from CD patients treated with combination therapy (infliximab/ immunomodulator) for at least 6 months [27]. This study showed that the trough infliximab levels of CD patients on combination therapy remained stable after discontinuation of the immunomodulator. The study also showed that, among patients who discontinued immunomodulator therapy, 38\% required infliximab dose escalation.

In the COMMIT randomized controlled trial of $126 \mathrm{CD}$ patients, which compared infliximab monotherapy with a combination of infliximab and methotrexate, patients started on prednisone within 6 weeks and tapered for 14 weeks were included and followed up for 50 weeks [28]. There was no significant difference between the infliximab and the combination infliximab/methotrexate group in terms of efficacy of therapy and corticosteroid-free remission rates at 54 weeks. This study included patients already started on steroids as well as long-standing CD, and this may have affected the results [28].

Magro et al evaluated the predictive factors of $\mathrm{CD}$ phenotype progression by prospectively collecting data on 736 patients and following them over 12.3 years. Phenotype progression was defined as progression from a non-stenosing non-penetrating behavior (B1) to a fibro-stenosing (B2) and/or penetrating phenotype (B3). Azathioprine use as monotherapy or in combination with anti-TNF in patients with phenotype $\mathrm{B} 1 \mathrm{CD}$ resulted in a delay in phenotype progression compared to untreated patients, with hazard ratios (HR) for disease progression of 0.15 (95\% confidence interval [CI]
0.113-0.199) for monotherapy and 0.33 (95\%CI $0.212-0.507)$ for combination therapy [29].

\section{Adalimumab}

The DIAMOND study evaluated the efficacy of adalimumab with or without the addition of azathioprine [30]. In this prospective, multicenter, open-label randomized clinical trial, 177 biologic- and thiopurine-naïve patients with moderate-tosevere CD were included and followed for 52 weeks. The primary endpoint of the study was clinical remission at 26 weeks. Of the patients in the monotherapy group, $71.8 \%$ met the primary endpoint, compared to $68.1 \%$ in the combination group $(\mathrm{P}=0.63)$. In this study, $63.8 \%$ of patients in the monotherapy group showed endoscopic improvement at 26 weeks compared to $84.2 \%$ in the combination group $(\mathrm{P}=0.019)$. In addition, pharmacokinetic analyses of adalimumab at 26 weeks revealed higher trough levels of adalimumab and a lower ratio of antibody to adalimumab in the combination group compared to the monotherapy group; however, these differences were not significant [30].

A meta-analysis from 2014 showed that the response rates of CD improve with combination therapy (using adalimumab) compared with adalimumab monotherapy, but there was no clear improvement in the 1-year remission rates or the need for dose escalation [16]. In a different meta-analysis from 2017, Chalboub et al showed that a combination of adalimumab and immunomodulators was not superior to adalimumab monotherapy for the induction and maintenance of remission in $\mathrm{CD}$, but that combination therapy was associated with lower immunogenicity [31].

\section{Infliximab and adalimumab}

Cosnes et al retrospectively assessed the response rates of biologic-naïve $\mathrm{CD}$ patients who received biologic monotherapy (adalimumab or infliximab) and those who received at least 4-6 months of initial combination therapy with anti-TNF- $\alpha$ and azathioprine or methotrexate [32]. Response rates at 6 months and at 2 years of patients from the combination therapy group were superior to those from anti-TNF- $\alpha$ monotherapy (whether infliximab or adalimumab). Additionally, drug survival was longer with combination therapy compared to biologic monotherapy [32]. There were no differences noted between the type of biologic therapy amongst the monotherapy or the combination therapy groups.

More recently, Ananthakrishnan et al published the results of a multicenter prospective cohort that examined the effect of combination therapy on disease outcome for both CD and UC [33]. It was shown that the benefit of combination therapy was more pronounced amongst CD patients with complicated disease, especially when combination therapy was initiated early after diagnosis.

The REACT study assessed whether early combined immunosuppression (anti-TNF- $\alpha$ and immunomodulator) is 
better than the conventional step-up treatment for CD [34]. This cluster randomized controlled study of more than $1000 \mathrm{CD}$ patients showed no significant change in clinical remission, but found a decrease in 2-year need for surgery, hospital admission and serious CD-related complications in the group in which immunomodulators were introduced early [34]. This study had limitations, including the lack of ileocolonoscopies to assess disease activity and that treatment was compared to standard of care. Hoekman et al evaluated the long-term outcomes of early combined immunosuppression vs. conventional management in CD patients over a median follow-up duration of 8 years. Again, there was no difference in the clinical remission rates. In addition, the rates of endoscopic remission, hospitalization, surgery and new fistulas were similar between the 2 groups. However, there was a decrease in the rates of relapse, use of anti-TNF agents and corticosteroids in the top-down strategy compared to the step-up strategy [35].

A meta-analysis by Jones et al evaluated 11 randomized controlled trials of anti-TNF- $\alpha$ agents (infliximab, adalimumab and certolizumab pegol) in CD patients who had already failed immunomodulator therapy [36]. These patients were not naïve to anti-TNF- $\alpha$ nor immunomodulator therapy and had luminal or fistulizing $\mathrm{CD}$. This meta-analysis found that combination therapy was not more effective than biologic monotherapy at inducing 6-month remission, inducing a response, maintaining a response, or inducing partial or complete fistula closure [36]. A recent retrospective cohort study showed no benefit of combination therapy over monotherapy, but this study had a major limitation pertaining to the nature of administrative data [37]. In this study, combination therapy was defined as one prescription for immunomodulatory medication, so filling the immunomodulator prescription 30 days before or after the initiation of anti-TNF therapy would count as combination therapy [37].

Peyrin-Biroulet et al conducted a multicenter retrospective study in which the short-term effect of anti-TNF- $\alpha$ monotherapy was evaluated at weeks 4 to 12 , as no response, partial response or complete response [38]. A total of 350 adults with CD received anti-TNF- $\alpha$ monotherapy (51\% infliximab, $49 \%$ adalimumab) and were followed for a mean duration of 42 months. Immunomodulators were introduced in patients who lost response to the anti-TNF- $\alpha$ therapy. An immunomodulator was initiated in 53 patients, with a greater need for immunomodulator initiation in patients on infliximab compared to those on adalimumab $(\mathrm{P}=0.0058)$ and in patients on second-/third-/fourth-line anti-TNF- $\alpha$ therapy compared to first-line anti-TNF- $\alpha(\mathrm{P}=0.014)$. It was noted that, at last follow up, 38 patients $(73.1 \%)$ were in clinical remission and that only $6 \%$ of patients were anti-TNF- $\alpha$ non-responders, indicating that anti-TNF- $\alpha$ monotherapy with infliximab is very effective for short-term treatment of CD [38]. Infliximab was also found to avoid the need for surgery. The percentage of intestinal resections in patients in their fifth year of antiTNF- $\alpha$ monotherapy was $24.9 \%$ and the rate of hospitalization was $19.2 \%$ [38]. Table 1 displays the different studies that used combination therapy or monotherapy in the treatment of CD.

Targownik et al compared IBD-related complications between anti-TNF-naïve patients started on monotherapy and those started on combination therapy. In this populationbased study, combination therapy showed better treatment effectiveness in CD patients $(n=852)$. There was a longer time until hospitalization or until a change of anti-TNF agent was required; however, surgery rates and the use of corticosteroids did not differ between the 2 arms [39]. In a retrospective study that evaluated the persistence of all biologic drugs (infliximab, adalimumab, certolizumab, golimumab and vedolizumab) in $5612 \mathrm{CD}$ and 3533 UC patients, the risk of biologic discontinuation was lower in patients initiated on immunomodulators 30 days prior to initiation of the biologic therapy, compared to those on biologic monotherapy, with a HR of 0.22 (95\%CI 0.16-0.32) [40].

\section{Vedolizumab}

The 2018 American College of Gastroenterology (ACG) guidelines on management of $\mathrm{CD}$ recommend vedolizumab use, with or without an immunomodulator, for the induction of symptomatic remission in patients with moderately to severely active CD [20]. In a study by Allegretti et al, clinical response or remission at week 54 in 96 patients with CD was higher in those on combination therapy, with an odds ratio (OR) of 2.71 (95\%CI 1.11-6.57) for those on an immunomodulator from the beginning and an OR of 11.49 (95\%CI 3.16-41.75) for those who had an immunomodulator added on a later basis [41]. Based on post hoc analyses from GEMINI 1 and 2, Colombel et al found no clinical benefit at either week 6 or week 52 from combining vedolizumab with an immunomodulator, compared to using it as monotherapy [42,43].

As stated in the ACG guidelines, prospective clinical trials comparing vedolizumab use as monotherapy vs. combination therapy with an immunonodulator are still lacking, and it is unclear whether the combination strategy works via a synergistic effect or by reducing the immunogenicity, which is already very low to start with (4\%) [44].

In a retrospective study by $\mathrm{Hu}$ et al, which included 549 patients (236 UC and $286 \mathrm{CD}$ ) on vedolizumab maintenance therapy of whom $131(23.9 \%)$ were on combination therapy, with either thiopurine $(n=78)$ or methotrexate $(n=53)$, there was no difference in clinical response or remission rates, endoscopic remission or persistence of therapy between the monotherapy and the combination therapy groups at 1-year follow up [45].

\section{Ustekinumab}

CD patients enrolled in the IM-UNITI pivotal clinical trial were followed for up to 5 years after induction and maintenance treatment with ustekinumab. This long-term extension (LTE) revealed that $55.1 \%$ of $C D$ patients who entered the LTE and who were on the 8-week dosing interval of ustekinumab were in remission at week 152, compared to $56.3 \%$ in those who received the 12 -week interval dosing. No association was found between the remission rate at week 152 and the use of an immunomodulator at week 44 [46]. 
Table 1 Summary of studies using combination therapy or monotherapy in patients with CD

\begin{tabular}{|c|c|c|c|c|c|c|c|}
\hline Study & Design & $\begin{array}{l}\text { Disease } \\
\text { type }\end{array}$ & $\begin{array}{l}\text { Number } \\
\text { and type } \\
\text { of patients } \\
\text { included }\end{array}$ & $\begin{array}{l}\text { Outcomes } \\
\text { studied }\end{array}$ & Drugs studied & Results & Limitations \\
\hline SONIC [22] & RCT & $\mathrm{CD}$ & $\begin{array}{l}508 \\
\text { Moderate- } \\
\text { to-severe } \\
\mathrm{CD} \\
\text { patients }\end{array}$ & $\begin{array}{l}\text { Induction and } \\
\text { maintenance of } \\
\text { corticosteroid- } \\
\text { free remission }\end{array}$ & $\begin{array}{l}\text { IFX vs. AZA vs. } \\
\text { combination } \\
\text { therapy (IFX + } \\
\text { AZA) }\end{array}$ & $\begin{array}{l}\text { Corticosteroid- } \\
\text { free clinical } \\
\text { remission at } 26 \\
\text { weeks and mucosal } \\
\text { healing better } \\
\text { for combination } \\
\text { therapy arm }\end{array}$ & $\begin{array}{l}\text { Information on } \\
\text { hospitalization } \\
\text { and } \\
\text { surgery rates are } \\
\text { lacking } \\
\text { The trial is not a } \\
\text { long-term disease } \\
\text { modification } \\
\text { trial }\end{array}$ \\
\hline $\begin{array}{l}\text { COMMIT } \\
{[28]}\end{array}$ & RCT & $\mathrm{CD}$ & $\begin{array}{l}126 \\
\text { Patients on } \\
\text { steroids for } \\
\text { induction } \\
\text { of } \\
\text { remission }\end{array}$ & $\begin{array}{l}\text { Primary } \\
\text { outcome: Time } \\
\text { to treatment } \\
\text { failure, defined } \\
\text { as lack of } \\
\text { prednisone- } \\
\text { free remission } \\
\text { at week } 14 \\
\text { or failure } \\
\text { to maintain } \\
\text { remission } \\
\text { through week } 50\end{array}$ & $\begin{array}{l}\text { IFX vs. combo (IFX } \\
+ \text { MTX) }\end{array}$ & $\begin{array}{l}\text { No difference } \\
\text { between the IFX } \\
\text { monotherapy and } \\
\text { the combination } \\
\text { IFX and MTX } \\
\text { groups in terms of } \\
\text { efficacy of therapy } \\
\text { and corticosteroid- } \\
\text { free remission rates } \\
\text { at } 54 \text { weeks }\end{array}$ & $\begin{array}{l}\text { Patients already } \\
\text { started on } \\
\text { steroids and } \\
\text { patients with } \\
\text { long-standing } \\
\text { CD were } \\
\text { included } \\
\text { and this may } \\
\text { have shifted the } \\
\text { results }\end{array}$ \\
\hline $\begin{array}{l}\text { DIAMOND } \\
{[30]}\end{array}$ & $\begin{array}{l}\text { Open-label } \\
\text { prospective } \\
\text { randomized } \\
\text { trial }\end{array}$ & $\mathrm{CD}$ & $\begin{array}{l}177 \\
\text { Biologic } \\
\text { and } \\
\text { thiopurine } \\
\text { naive } \\
\text { patients } \\
\text { with } \\
\text { moderate- } \\
\text { to-severe } \\
\text { CD }\end{array}$ & $\begin{array}{l}\text { Clinical } \\
\text { remission at } \\
\text { week } 26\end{array}$ & $\begin{array}{l}\text { ADA vs. } \\
\text { combination } \\
\text { therapy (ADA + } \\
\text { AZA) }\end{array}$ & $\begin{array}{l}\text { Clinical remission } \\
\text { at } 26 \text { weeks: } 71.8 \% \\
\text { monotherapy vs. } \\
68.1 \% \text { combination } \\
\text { group ( } \mathrm{P}=0.63) \\
\text { Endoscopic response } \\
\text { at } 26 \text { weeks: } 63.8 \% \\
\text { in the monotherapy } \\
\text { group vs. } 84.2 \% \text { in } \\
\text { the combination } \\
\text { group }(\mathrm{P}=0.019)\end{array}$ & $\begin{array}{l}\text { Open-label study } \\
\text { Statistically } \\
\text { underpowered }\end{array}$ \\
\hline $\begin{array}{l}\text { REACT } \\
{[34]}\end{array}$ & $\begin{array}{l}\text { Cluster } \\
\text { RCT }\end{array}$ & $\mathrm{CD}$ & 1,727 & $\begin{array}{l}\text { Proportion } \\
\text { of patients in } \\
\text { corticosteroid- } \\
\text { free remission at } \\
12 \text { months at the } \\
\text { practice level }\end{array}$ & $\begin{array}{l}\text { Early combined } \\
\text { immunosuppression } \\
\text { with anti-TNF } \\
\text { (IFX or ADA) and } \\
\text { immunomodulator } \\
\text { (AZA or MTX } \\
\text { or 6-MP) vs. } \\
\text { conventional } \\
\text { therapy for the } \\
\text { treatment of CD }\end{array}$ & $\begin{array}{l}\text { No significant } \\
\text { change in clinical } \\
\text { remission, but } \\
\text { decrease in } \\
\text { 2-year need for } \\
\text { surgery, hospital } \\
\text { admission and } \\
\text { serious CD-related } \\
\text { complications in } \\
\text { the group with early } \\
\text { introduction of } \\
\text { immunomodulators } \\
\text { in more than } 1000 \\
\text { CD patients }\end{array}$ & $\begin{array}{l}\text { Lack of } \\
\text { ileocolonoscopies } \\
\text { to assess } \\
\text { disease activity } \\
\text { Treatment was } \\
\text { compared to } \\
\text { standard of care }\end{array}$ \\
\hline
\end{tabular}

RCT, randomized controlled trial; $C D$, Crohn's disease; IFX, infliximab; AZA, azathioprine; MTX, methotrexate; ADA, adalimumab; TNF, tumor necrosis factor; 6-MP, 6-mercaptopurine

Data on 122 patients with anti-TNF- $\alpha$ refractory $C D$ was collected from the GETAID study. Immunosuppression use concomitantly with ustekinumab at inclusion was a predictive factor of clinical efficacy at 3 months, with an OR of 5.43 (95\%CI 1.14-25.77); $\mathrm{P}=0.03$. However, it should be noted that a minority of patients, $15 \%$ (18/122), were on combination therapy and that the follow-up period was short [47].

In a study by Battat, $62 \mathrm{CD}$ patients received the induction doses of ustekinumab, which consisted of $90 \mathrm{mg}$ subcutaneously at weeks 0,1 and 2 , and were then maintained 
on $90 \mathrm{mg}$ subcutaneously every 4 or 8 weeks and followed up for 26 weeks or longer. The rates of steroid-free clinical remission, the endoscopic response and remission, and the ustekinumab concentrations were similar between patients on ustekinumab monotherapy and those who received concomitant immunosuppressant [48].

Adedokun et al conducted a study on the pharmacokinetics of ustekinumab in moderate-to-severe CD patients. They measured the drug serum concentrations during the induction and maintenance phases over 52 weeks. There was an association between the serum drug concentrations and the clinical remission rates, without evidence of an association with immunomodulator use [49]. Based on the above, ustekinumab is therefore recommended to be used as monotherapy in view of the absence of added benefit from an immunomodulator. A study by $\mathrm{Hu}$ et al, which included a total of 363 patients (4 UC and $359 \mathrm{CD}$ patients) on ustekinumab maintenance therapy of whom $120(33.1 \%)$ were on combination therapy, either thiopurine $(n=57)$ or methotrexate $(n=63)$, found no difference in clinical response or remission rates, endoscopic remission or persistence of therapy, between the monotherapy and the combination therapy groups at 1 year follow up [45].

\section{UC}

Monoclonal anti-TNF- $\alpha$ drugs used in the treatment of UC include infliximab, adalimumab, and golimumab [50-52]. The ACG, AGA and ECCO guidelines recommend the use of anti-TNF- $\alpha$ medications for high-risk patients and for patients who fail first-line therapy [53,54]. More recently, ustekinumab and vedolizumab have been approved as first-line therapy in patients with moderate-to-severe UC.

\section{Infliximab}

The ACT1 and ACT2 trials showed that infliximab is effective in treating moderate-to-severe active UC [55]. Enrolled patients in both the placebo and infliximab arms of these trials were on concomitant medications (corticosteroids, 5-ASA, or immunomodulators), so these trials were not conclusive regarding the superiority of monotherapy or combination therapy in UC [55]. The UC-SUCCESS trial examined the outcomes of moderate-to-severe, biologicnaïve but azathioprine-exposed, UC patients randomized to receive combination therapy with infliximab and azathioprine, infliximab monotherapy or azathioprine monotherapy [15]. The results showed that combination therapy is superior to infliximab monotherapy and azathioprine monotherapy in terms of achieving corticosteroid-free remission at 16 weeks and in terms of significantly improved mucosal healing [15].

A systematic review conducted by Christophorou et al included 765 patients from 4 controlled trials. Of these, 389 patients were on infliximab monotherapy while the remaining 376 patients were on combination therapy. At 4-6 months from therapy, clinical remission rates were significantly higher in patients receiving combination therapy compared to infliximab monotherapy [56].

Armuzzi et al conducted a study to look for the predictors of steroid-free clinical benefit in the long term in patients with steroid-dependent UC [57]. Of 126 patients, 96 received a clinical benefit, and 46 maintained the response for the followup period of 41.5 months. An independent predictor of response was the use of infliximab in combination with thiopurines, with a HR of 3.98 (95\%CI 1.73-9.14); $\mathrm{P}<0.001$ [57].

Later in 2015, a retrospective multicenter French study examined the efficacy of combination therapy with thiopurines and infliximab beyond 6 months amongst UC patients in prolonged steroid-free clinical remission [58]. This study showed no difference in colectomy rates between the monotherapy (infliximab alone) and combination therapy patients, but the latter group had fewer clinical relapses, with an inverse relationship beyond 9 months of combination therapy [58]. Based on these results, combination therapy should be maintained for at least 9 months, but studies are lacking regarding the optimal duration for combination therapy beyond which one treatment should be withdrawn. Table 2 displays the different studies that used combination therapy or monotherapy in the treatment of ulcerative colitis.

\section{Infliximab and adalimumab}

A population-based study by Targownik et al did not show a difference in treatment effectiveness amongst anti-TNF-naïve UC patients receiving monotherapy compared to combination therapy [39]. As previously mentioned, in a retrospective study by Chen et al that evaluated the persistence of all biologic drugs (infliximab, adalimumab, certolizumab, golimumab and vedolizumab) in $3533 \mathrm{UC}$ and $5612 \mathrm{CD}$ patients, the risk of biologic discontinuation was lower in patients initiated on immunomodulators 30 days prior to initiation of the biologic therapy, compared to those on biologic monotherapy, with a HR of 0.22 (95\%CI 0.16-0.32) [40].

\section{Golimumab}

A subanalysis of the PURSUIT (Program of Ulcerative Colitis Research Studies Utilizing an Investigational Treatment) study showed no difference in maintenance of remission between golimumab monotherapy and combination therapy (one third of patients received an immunomodulator along with golimumab) [59].

\section{Vedolizumab}

The study by Allegretti et al failed to demonstrate an increase in clinical response or remission at week 54 in UC patients who received vedolizumab in combination with an immunomodulator, compared to vedolizumab monotherapy; however, the sample size was small, consisting 
Table 2 Summary of studies using combination therapy or monotherapy in patients with UC

\begin{tabular}{|c|c|c|c|c|c|c|c|}
\hline Study & Design & $\begin{array}{l}\text { Disease } \\
\text { type }\end{array}$ & $\begin{array}{l}\text { Number } \\
\text { and type } \\
\text { of patients } \\
\text { included }\end{array}$ & $\begin{array}{l}\text { Outcomes } \\
\text { studied }\end{array}$ & Drug studied & Results & Limitations \\
\hline $\begin{array}{l}\text { ACT-1 } \\
\text { ACT-2 } \\
{[55]}\end{array}$ & RCT & UC & $\begin{array}{l}364 \text { in each } \\
\text { study } \\
\text { Moderate-to- } \\
\text { severe UC }\end{array}$ & $\begin{array}{l}\text { Efficacy } \\
\text { of IFX for } \\
\text { induction and } \\
\text { maintenance } \\
\text { therapy }\end{array}$ & $\begin{array}{l}\text { IFX vs. } \\
\text { placebo (both } \\
\text { arms could } \\
\text { have included } \\
\text { other drugs) }\end{array}$ & IFX is effective & $\begin{array}{l}\text { Enrolled patients in both } \\
\text { the placebo and } \\
\text { IFX arms of these trials } \\
\text { were on } \\
\text { concomitant medications } \\
\text { (corticosteroids, } \\
\text { 5-ASA, or } \\
\text { immunomodulators), so } \\
\text { these trials were not } \\
\text { conclusive regarding the } \\
\text { superiority of } \\
\text { monotherapy or } \\
\text { combination therapy in } \\
\text { UC }\end{array}$ \\
\hline $\begin{array}{l}\text { UC- } \\
\text { SUCCESS } \\
{[15]}\end{array}$ & RCT & UC & $\begin{array}{l}239 \\
\text { Anti-TNF } \\
\text { naïve } \\
\text { patients with } \\
\text { moderate-to- } \\
\text { severe UC }\end{array}$ & $\begin{array}{l}\text { Corticosteroid- } \\
\text { free clinical } \\
\text { remission at } \\
\text { week } 16\end{array}$ & $\begin{array}{l}\text { IFX mono, } \\
\text { AZA mono } \\
\text { or IFX + AZA } \\
\text { combination } \\
\text { therapy }\end{array}$ & $\begin{array}{l}\text { Higher } \\
\text { corticosteroid- } \\
\text { free remission } \\
\text { at } 16 \text { weeks and } \\
\text { better mucosal } \\
\text { healing in } \\
\text { patients on } \\
\text { IFX + AZA } \\
\text { compared to } \\
\text { monotherapy }\end{array}$ & $\begin{array}{l}\text { Patients in the AZA group } \\
\text { may not have had a } \\
\text { full chance to experience } \\
\text { an improvement in } \\
\text { mucosal healing at } 8 \text { weeks } \\
\text { Study was terminated } \\
\text { prematurely } \\
\text { Small amount of evaluable } \\
\text { data for IFX } \\
\text { antibody analysis }\end{array}$ \\
\hline $\begin{array}{l}\text { Armuzzi } \\
\text { et al [57] }\end{array}$ & $\begin{array}{l}\text { Retrospective } \\
\text { observational } \\
\text { study }\end{array}$ & UC & $\begin{array}{l}126 \\
\text { Steroid- } \\
\text { dependent } \\
\text { UC }\end{array}$ & $\begin{array}{l}\text { Sustained } \\
\text { clinical } \\
\text { response in } \\
\text { patients who } \\
\text { achieved } \\
\text { clinical } \\
\text { remission or } \\
\text { response after } \\
\text { IFX induction } \\
\text { and colectomy- } \\
\text { free survival }\end{array}$ & $\begin{array}{l}\text { IFX vs. } \\
\text { combination } \\
\text { (IFX }+ \\
\text { thiopurine) }\end{array}$ & $\begin{array}{l}\text { Use of IFX in } \\
\text { combination } \\
\text { with } \\
\text { thiopurines } \\
\text { was an } \\
\text { independent } \\
\text { predictor of } \\
\text { response }\end{array}$ & $\begin{array}{l}\text { Absence of a control arm } \\
\text { of patients treated } \\
\text { only with AZA } \\
\text { Lack of short-term } \\
\text { endoscopic data }\end{array}$ \\
\hline $\begin{array}{l}\text { Filippi } \\
\text { et al [58] }\end{array}$ & $\begin{array}{l}\text { Retrospective } \\
\text { observational } \\
\text { study }\end{array}$ & UC & $\begin{array}{l}82 \\
\text { Prolonged } \\
\text { steroid-free } \\
\text { remission }\end{array}$ & $\begin{array}{l}\text { Disease relapse } \\
\text { defined by } \\
\text { clinical relapse } \\
\text { requiring a } \\
\text { change of } \\
\text { treatment, IFX } \\
\text { failure, and } \\
\text { colectomy }\end{array}$ & $\begin{array}{l}\text { Thiopurines } \\
\text { and IFX vs. } \\
\text { IFX } \\
\text { monotherapy }\end{array}$ & $\begin{array}{l}\text { No difference } \\
\text { in colectomy } \\
\text { rates between } \\
\text { the IFX } \\
\text { monotherapy } \\
\text { and } \\
\text { combination } \\
\text { therapy } \\
\text { patients } \\
\text { Combination } \\
\text { therapy had } \\
\text { fewer clinical } \\
\text { relapses with } \\
\text { an inverse } \\
\text { relationship } \\
\text { beyond } 9 \\
\text { months of } \\
\text { combination } \\
\text { therapy }\end{array}$ & $\begin{array}{l}\text { Retrospective } \\
\text { observational study, with } \\
\text { subjective management } \\
\text { of AZA withdrawal or } \\
\text { colectomy decision } \\
\text { Data concerning mucosal } \\
\text { healing were not } \\
\text { analyzed, nor IFX trough } \\
\text { levels or ATI }\end{array}$ \\
\hline
\end{tabular}


of only 40 patients [41]. Hu et al did not show a difference in clinical response or remission rates, endoscopic remission or persistence of therapy, between vedolizumab monotherapy and combination therapy at 1-year follow up [45]. The study included a total of 549 patients (236 UC and $286 \mathrm{CD}$ ) on vedolizumab maintenance therapy, of whom 131 (23.9\%) were on combination therapy, either with thiopurine $(n=78)$ or methotrexate $(n=53)$.

\section{Ustekinumab}

$\mathrm{Hu}$ et al also evaluated 363 patients (4 UC and $359 \mathrm{CD}$ ) on ustekinumab maintenance therapy, of whom 120 (33.1\%) were on combination therapy, either thiopurine $(n=57)$ or methotrexate $(n=63)$. Similar to the results with vedolizumab, at 1-year follow up there was no difference in clinical response or remission rates, endoscopic remission or persistence of therapy, between the monotherapy and the combination therapy groups [45].

\section{Infections and malignancy}

From the SONIC trial, the rates of serious infections were not significantly different between the combination therapy arm and the infliximab monotherapy arm (3.9\% and $4.9 \%$, respectively); the overall evidence was rated moderate-quality because of imprecision [22]. Similarly, in a systematic review and meta-analysis by Chalhoub et al, the rates of opportunistic infections in $\mathrm{CD}$ patients were not different between the adalimumab monotherapy arm and the combination therapy with immunomodulators arm. However, subgroup analysis revealed higher odds of opportunistic infections in patients who were anti-TNF-experienced, with an OR of 2.44 (95\%CI 1.07-5.54) [31]. Other studies of the safety of anti-TNF- $\alpha$ drug monotherapy vs. combination therapy are of low quality. They do suggest a slight increase in lymphoma risk amongst patients with combination therapy, but comparable risk for serious infections amongst these 2 groups. Using the TREAT registry, it is estimated that thiopurine treated patients had 10 more serious infections amongst 1000 patients compared to patients not treated with thiopurines [60].

Using the CESAME (Cancers Et Surrisque Associé aux Maladies Inflammatoires Intestinales En France) cohort, patients treated with thiopurines were found to have a HR as high as 5.28 (95\% CI 2.01 - 13.9) for the development of lymphoma [61]. The absolute risk for post-transplantlymphoma is $1 / 1000$ patient-years in the total IBD population exposed to thiopurines. The risk is lower, at $0.1 / 1000$ patient-years, for early post mononucleosis lymphomas and $0.05 / 1000$ patient-years for hepatosplenic T-cell lymphomas [62]. Patients receiving combination therapy (biologic agent and thiopurine) are at a higher risk for the development of lymphoma compared to patients on thiopurine alone $[61,63]$. Infliximab monotherapy has not been shown to increase the risk of lymphoma; however, results from studies of adalimumab suggest a slightly increased risk $[61,63,64]$. The adalimumab trials, however, were confounded by concomitant therapy with immunomodulators and disease state [64]. The risk of lymphomas in combination therapies is mainly due to azathioprine $[65,66]$, but also to anti-TNF [67]. It is always important to consider the risk of lymphoma when treating IBD patients with combination therapy, or even thiopurine monotherapy, especially in young males, who are the highest risk population for the development of the rare but deadly hepatosplenic natural killer T-cell lymphoma [68]. Osterman et al assessed the risk of malignancy with adalimumab monotherapy and compared it to the risk associated with combination adalimumab and azathioprine in patients with CD [69]. The results showed that adalimumab monotherapy does not increase the risk of malignancy compared to the general population. The rising concern about the increased risk of lymphoma with combination therapy has caused many physicians to favor anti-TNF- $\alpha$ monotherapy for the management of CD [68,70-73]. Indeed, the use of combination therapy among IBD patients was shown to be uncommon in a survey in France [74].

Patients treated with combination therapy had an increased risk of non-melanoma skin cancers and other malignancies [69]. This increased risk is due to the exposure to thiopurines. Several retrospective studies and the CESAME cohort have shown that thiopurines are associated with a higher risk of non-melanoma skin cancers compared to IBD patients not treated with thiopurines [75-78].

\section{Immunogenicity}

Immunogenicity is the formation of anti-drug antibodies against the anti-TNF- $\alpha$ biologic agent. The recently published PANTS study identified that the presence of HLA-DQA $1^{\star} 05$ is associated with the development of anti-drug antibodies in $90 \%$ of patients receiving anti-TNF monotherapy, and that in these patients the addition of an immunomodulator is advised [79]. There is sufficient evidence that the use of immunomodulators, such as a thiopurine (azathioprine or 6-mercaptopurine), or methotrexate in combination with the biologic agents reduces the risk of immunogenicity and increases serum concentration levels of the drug [68]. This effect leads to longer remission duration due to a sustained medical effect. The SONIC trial showed that infliximab levels in patients on combination therapy were $3.5 \mathrm{mg} / \mathrm{mL}$ compared to $1.6 \mathrm{mg} / \mathrm{mL}$ in the monotherapy arm, and that antibodies to infliximab were detected in $0.9 \%$ of patients on combination therapy compared to $14.6 \%$ of patients on monotherapy [22]. The meta-analysis by Chalhoub et al comparing adalimumab monotherapy to combination therapy with immunomodulators showed that the latter therapy resulted in lower levels of antibodies to adalimumab and thus decreased immunogenicity [31].

Regarding vedolizumab, the anti-drug antibodies are reduced when vedolizumab is combined with an immunomodulator [20]. In his review of the immunogenicity of vedolizumab, Rosario showed that the difference in the development of anti-vedolizumab antibodies between patients 
on monotherapy or combination therapy was minimal, being $4 \%$ vs. $3 \%$ respectively. Infusion-related reactions occurred in $5 \%$ of patients who tested continuously positive for anti-drug antibodies [44].

The formation of anti-ustekinumab antibodies is uncommon, occurring in $0.7 \%$ of CD patients by week 3 , as demonstrated in the CERTIFI trial, and in $2.3 \%$ after 1 year of maintenance therapy, as demonstrated in the IM-UNITI trial [80]. Recently, the LTE of the IM-UNITI trial looked at the immunogenicity with ustekinumab at week 156 and revealed that the occurrence of antibodies was still low after 3 years of treatment. More specifically, antibody formation occurred in only $4.6 \%(11 / 237)$ of patients on ustekinumab and in just $2.4 \%(2 / 82)$ of those on the 8 -week dosing interval. The rates of antibodies were low regardless of concomitant immunomodulator use, and their presence had no effect on the clinical outcomes [46].

Regarding immunomodulator therapy, Vermeire et al showed that both azathioprine and methotrexate are equally efficacious in improving the effect of infliximab and in the prevention of antibody formation and infusion reactions [11]. There have been cases where the addition of immunomodulators can lead to the disappearance of anti-infliximab antibodies, if present. The role of thiopurine in enhancing the therapeutic effects of the infliximab possibly involves increasing the levels of the thiopurine metabolite 6-thioguanine $[81,82]$; however, this correlation did not exist with adalimumab [83]. A trial in Belgium showed that, when an immunomodulator is initiated with adalimumab, the anti-adalimumab antibodies persisted and the adalimumab trough levels were not impacted by this intervention [84]. Studies on the pharmacokinetics of adalimumab and immunomodulators suggest that adding azathioprine to adalimumab will not affect the clearance of adalimumab [85-87].

The PANTS study examined the association between the genome and immunogenicity in naïve $\mathrm{CD}$ patients treated with infliximab or adalimumab. Patients carrying the HLADQA $1^{*} 05$ allele were at increased risk of development of anti-drug antibodies, with a HR of 1.90 (95\%CI 1.60-2.25). This association could help stratify patients, according to their HLA profile, into high vs. low risk of immunogenicity in order to guide in the treatment decision between monotherapy or combination therapy, respectively [79].

New studies have emerged regarding a proactive therapeutic drug monitoring (TDM) strategy that would result in steadily therapeutic biologic drug trough levels, as opposed to the rather reactive TDM strategy usually followed. In a study by Fernandes et al, patients in the proactive TDM group had higher mucosal healing rates $(73.2 \%$ vs. $38.9 \% ; \mathrm{P}<0.001)$ and lower surgical rates $(8.9 \%$ vs. $20.8 \% ; \mathrm{P}=0.032)$ compared to patients in the non-TDM reference group; both differences were significant [88]. A proactive TDM strategy could be an alternative to combination therapy in order to avoid the risks of the latter, however it increases the costs of therapy. Studies comparing these strategies are needed to reach a conclusion. Possible good candidates for the proactive TDM strategy would be those at highest risk of developing lymphoma on combination therapy, such as young Epstein-Barr virus seronegative male patients or adults above the age of 60-65 years [89].

\section{Combination therapy but for how long and what dose?}

The data support initiation of combination therapy, particularly with infliximab, but the optimal duration of continuing immunomodulator therapy prior to de-escalation remains controversial. It has been shown that the first 6 months of combination therapy are the most important to prevent immunogenicity [90]. Van Assche et al demonstrated that maintaining azathioprine with infliximab after 6 months of combination therapy does not provide any extra clinical advantage compared to the optimization of infliximab dosing; however, the authors did not assess the predictors of infliximab therapy failure after azathioprine withdrawal [26]. Six months after stopping azathioprine, the CRP levels were normal. Two years later, however, the CRP levels were higher, infliximab levels lower, but there was no need to escalate infliximab dosing compared to patients who continued azathioprine [26]. Retrospective studies have shown that continuing combination therapy for at least 2 years was associated with fewer IBD flares, fewer perianal complications, fewer switches to adalimumab, lower CRP levels, and stable infliximab doses [91,92]. Oussalah et al assessed the consequences of azathioprine discontinuation in CD patients on infliximab who had reached remission, and they found that stopping azathioprine will lead to relapse if the duration of the combination therapy is less than 27 months and if the patient already has active inflammation [91].

Regarding the dose of azathioprine, Yarur et al stated that patients were at increased risk of developing antibodies against infliximab when they had 6-thioguanine (6-TGN) levels below a value of $123 \mathrm{pmol} / 8 \times 10^{8}$ red blood cells (RBC) [93]. A study by Mogensen et al showed similar results, whereby antibodies against anti-TNF were not detected with 6 -TGN values above $117 \mathrm{pmol} / 8 \times 10^{8} \mathrm{RBC}$ [94]. Compared to the 6-TGN threshold of $235 \mathrm{pmol} / 8 \times 10^{8} \mathrm{RBC}$ used for clinical efficacy in patients on azathioprine monotherapy [95], lower doses of azathioprine during combination therapy would be enough to prevent immunogenicity, therefore decreasing the risk of intolerance with the weight-based regimen.

\section{Withdrawal of biologic therapy}

IBD patients should be followed regularly to ensure remission is maintained. Accordingly, modifications to the medications can take place, such as de-escalation of immunomodulators or anti-TNF- $\alpha$ agents.

In the STORI trial, Louis et al prospectively investigated whether infliximab can be safely interrupted in CD patients treated with combination therapy for at least 1 year and who had been in remission for over 6 months [96]. The study showed that the 1 -year relapse rate was $43.9 \%$ and the risk factors for relapse included male sex, absence of surgical resection, leukocyte counts $>6 \times 10^{9} \mathrm{~L}$, 
hemoglobin $\leq 145 \mathrm{~g} / \mathrm{L}, \mathrm{CRP} \geq 5 \mathrm{mg} / \mathrm{L}$, and fecal calprotectin $\geq 300$ $\mu \mathrm{g} / \mathrm{g}$. Patients with no more than 2 of the above risk factors had a $15 \%$ chance of relapse within 1 year [96]. That STORI cohort was followed-up over a longer period of time and it was found that at 7 years from infliximab withdrawal, $21 \%$ of the patients did not need reintroduction of infliximab or any other biologic agent and did not suffer from any major complication, $70.2 \%$ of patients had no infliximab restart failures or major complications, whereas $18.5 \%$ of patients had major complications, defined as either a surgical resection or new complex perianal lesions before or after the resumption of infliximab. The risk factors for major complications were an upper gastrointestinal disease location, leukocyte count $\geq 5 \times 10^{9} / \mathrm{L}$ and hemoglobin $\leq 12.5 \mathrm{~g} / \mathrm{dL}$ at the time of infliximab withdrawal [97].

Torres et al suggested that 5 specific factors should be assessed in patients in clinical remission, in order to decide on their maintenance therapy. These factors include: patient demographics, disease features, treatment history, current disease status and patient's preferences and willingness to accept various risks. The factors favoring de-escalation therapy were young males and older patients, short disease extent and short duration between diagnosis and start of effective therapy, stable therapy with no need for dose-escalation, mucosal healing and biological remission, trough levels (low for anti-TNF/elevated for immunomodulator), prolonged sustained remission, and a history of cancer or serious infections. On the other hand, factors favoring continuation of maintenance therapy include young age at diagnosis, perianal disease, ileal disease, extensive disease, previous surgery, previous immunomodulator failure, previous need for anti-TNF- $\alpha$ therapy, relapsing course, elevated markers of inflammation, mucosal ulcerations, transmural thickening, short duration of remission, and the absence of comorbidities. Torres et al reported that stopping immunomodulator therapy after remission will lead to relapse in $75 \%$ of the patients (in a window of 5 years) [98]. Amongst CD patients receiving combination therapy, those who discontinue immunomodulator therapy will have similar relapse rates even if the immunomodulator is continued. This same intervention in UC, however, will cause a decrease in the number of patients in remission [99]. Some argued previously that treatment of any kind can be stopped when the patient is in "deep" remission, but the risk of relapse would still be high, and thus this ideology was abandoned $[96,100]$.

A recent retrospective study by Ampuero et al evaluated 75 CD patients who had achieved remission within 6 months of starting an immunomodulator and anti-TNF- $\alpha$ combination therapy, when one of the 2 drugs was withdrawn. As a result, $28 \%$ of patients relapsed. This relapse rate was mainly affected by CRP levels, where CRP $>5 \mathrm{mg} / \mathrm{L}$ indicated a 6-times increased risk of relapse 1 year after combination therapy discontinuation $[101,102]$. The anti-TNF- $\alpha$ discontinuation was more frequent than the immunomodulator discontinuation because it is more expensive [101]. Monotherapy was deemed effective in this study. A European panel has recently achieved a consensus that anti-TNF- $\alpha$ withdrawal is best after 2 years into clinical remission [103].

\section{Concluding remarks}

IBD treatments are diverse and evolving but significant unmet needs remain. Physicians must rely on clinical criteria, endoscopic findings, imaging results, genetic testing (HLA typing) and biological markers to categorize the patient's disease as low- or high-risk. If the disease behavior is indolent then a step-up strategy is appropriate, in which case intensive therapy and immunosuppression may be avoided. However, if the disease behavior is aggressive, then a top-down strategy is more appropriate, with the early initiation of combination therapy in order to subsequently avoid complications $[35,104]$.

Physicians aim at achieving remission as early as possible in the disease course. According to studies, the road to remission is the early initiation of combination therapy in patients with moderate-to-severe CD [22] and in UC patients refractory to corticosteroids [15]. However, concerns about the increased risk of opportunistic infections and malignancies, specifically lymphomas, with the use of combination therapy make this option less appealing.

Disease evolution and response to therapy are patientspecific. Factors that should be put into the equation include patient age, sex, inflammatory burden (depth of ulcers, presence of systemic inflammation), disease extent and duration, previous treatment exposure and response to therapy, as well as surgical history. Physicians need to follow a patient-oriented approach by assessing the risks of therapy and the risks of an ineffectively treated IBD.

\section{References}

1. Crohn's and Colitis Foundation of America. The facts about inflammatory bowel diseases. 2019. Available from: https:// www.crohnscolitisfoundation.org/sites/default/files/2019-02/ Updated\%20IBD\%20Factbook.pdf [Accessed 14 May 2021].

2. Burisch J, Jess T, Martinato M, Lakatos PL; ECCO -EpiCom. The burden of inflammatory bowel disease in Europe. J Crohns Colitis 2013;7:322-337.

3. Kaplan GG. The global burden of IBD: from 2015 to 2025. Nat Rev Gastroenterol Hepatol 2015;12:720-727.

4. Calkins BM, Lilienfeld AM, Garland CF, Mendeloff AI. Trends in incidence rates of ulcerative colitis and Crohn's disease. Dig Dis Sci 1984;29:913-920.

5. Ekbom A, Helmick C, Zack M, Adami HO. The epidemiology of inflammatory bowel disease: a large, population-based study in Sweden. Gastroenterology 1991;100:350-358.

6. Gajendran M, Loganathan P, Catinella AP, Hashash JG. A comprehensive review and update on Crohn's disease. Dis Mon 2018;64:20-57.

7. Gajendran M, Loganathan P, Jimenez G, et al. A comprehensive review and update on ulcerative colitis. Dis Mon 2019;65:100851.

8. Chande N, Townsend CM, Parker CE, MacDonald JK. Azathioprine or 6-mercaptopurine for induction of remission in Crohn's disease. Cochrane Database Syst Rev 2016;10:CD000545.

9. Herfarth $\mathrm{HH}$, Kappelman MD, Long MD, Isaacs KL. Use of methotrexate in the treatment of inflammatory bowel diseases. Inflamm Bowel Dis 2016;22:224-233.

10. Baert F, Noman $M$, Vermeire $S$, et al. Influence of immunogenicity on the long-term efficacy of infliximab in Crohn's disease. N Engl J 
Med 2003;348:601-608.

11. Vermeire S, Noman M, Van Assche G, Baert F, D’Haens G, Rutgeerts P. Effectiveness of concomitant immunosuppressive therapy in suppressing the formation of antibodies to infliximab in Crohn's disease. Gut 2007;56:1226-1231.

12. Rubin DT, Ananthakrishnan AN, Siegel CA, Sauer BG, Long MD. ACG Clinical Guideline: Ulcerative colitis in adults. Am J Gastroenterol 2019;114:384-413.

13. Terdiman JP, Gruss CB, Heidelbaugh JJ, Sultan S, Falck-Ytter YT; AGA Institute Clinical Practice and Quality Management Committee. American Gastroenterological Association Institute guideline on the use of thiopurines, methotrexate, and anti-TNF- $\alpha$ biologic drugs for the induction and maintenance of remission in inflammatory Crohn's disease. Gastroenterology 2013;145:1459-1463.

14. Dassopoulos T, Cohen RD, Scherl EJ, Schwartz RM, Kosinski L, Regueiro MD. Ulcerative colitis care pathway. Gastroenterology 2015; 149:238-245.

15. Panaccione R, Ghosh S, Middleton S, et al. Combination therapy with infliximab and azathioprine is superior to monotherapy with either agent in ulcerative colitis. Gastroenterology 2014;146:392-400.

16. Kopylov U, Al-Taweel T, Yaghoobi M, et al. Adalimumab monotherapy versus combination therapy with immunomodulators in patients with Crohn's disease: a systematic review and metaanalysis. J Crohns Colitis 2014;8:1632-1641.

17. Gisbert JP, Panés J. Loss of response and requirement of infliximab dose intensification in Crohn's disease: a review. Am J Gastroenterol 2009;104:760-767.

18. D'Haens GR, Panaccione R, Higgins PD, et al. The London Position Statement of the World Congress of Gastroenterology on Biological Therapy for IBD with European Crohn's and Colitis Organization: when to start, when to stop, which drug to choose, and how to predict response? Am J Gastroenterol 2011;106:199-212.

19. Torres J, Bonovas S, Doherty G, et al. ECCO guidelines on therapeutics in Crohn's disease: medical treatment. J Crohns Colitis 2020;14:4-22.

20. Lichtenstein GR, Loftus EV, Isaacs KL, Regueiro MD, Gerson LB, Sands BE. ACG Clinical Guideline: Management of Crohn's disease in adults. Am J Gastroenterol 2018;113:481-517.

21. Feuerstein JD, Isaacs KL, Schneider Y, Siddique SM, FalckYtter Y, Singh S; AGA Institute Clinical Guidelines Committee. AGA clinical practice guidelines on the management of moderate to severe ulcerative colitis. Gastroenterology 2020;158:1450-1461.

22. Colombel JF, Sandborn WJ, Reinisch W, et al; SONIC Study Group. Infliximab, azathioprine, or combination therapy for Crohn's disease. N Engl J Med 2010;362:1383-1395.

23. D’Haens G, Baert G, van Assche G, et al. Early combined immunosuppression or conventional management in patients with newly diagnosed Crohn's disease: an open randomised trial. Lancet 2008;371:660-667.

24. Colombel JF, Reinisch W, Mantzaris GJ, et al. Randomised clinical trial: deep remission in biologic and immunomodulator naïve patients with Crohn's disease - a SONIC post hoc analysis. Aliment Pharmacol Ther 2015;41:734-746.

25. Hazlewood GS, Rezaie A, Borman M, et al. Comparative effectiveness of immunosuppressants and biologics for inducing and maintaining remission in Crohn's disease: a network metaanalysis. Gastroenterology 2015;148:344-354.e5; quiz e14-e15.

26. Van Assche G, Magdelaine-Beuzelin C, D'Haens G, et al. Withdrawal of immunosuppression in Crohn's disease treated with infliximab maintenance: a randomized trial. Gastroenterology 2008;134:1861-1868.

27. Drobne D, Bossuyt P, Breynaert C, et al. Withdrawal of immunomodulators after co-treatment does not reduce trough level of Infliximab in patients with Crohn's disease. Clin Gastroenterl Hepatol 2015;13:514-521.e4.
28. Feagan BG, McDonald JW, Panaccione R, et al. Methotrexate in combination with infliximab is no more effective than infliximab alone in patients with Crohn's disease. Gastroenterology 2014;146:681-688.

29. Magro F, Rodrigues-Pinto E, Coelho R, et al. Is it possible to change phenotype progression in Crohn's disease in the era of immunomodulators? Predictive factors of phenotype progression. Am J Gastroenterol 2014;109:1026-1036.

30. Matsumoto T, Motoya S, Watanabe K, et al. Adalimumab monotherapy and a combination with azathioprine for Crohn's disease: a prospective, randomized trial. J Crohns Colitis 2016;10:1259-1266.

31. Chalhoub JM, Rimmani HH, Gumaste VV, Sharara AI. Systematic review and meta-analysis: adalimumab monotherapy versus combination therapy with immunomodulators for induction and maintenance of remission and response in patients with Crohn's disease. Inflamm Bowel Dis 2017;23:1316-1327.

32. Cosnes J, Sokol H, Bourrier A, et al. Adalimumab or infliximab as monotherapy, or in combination with an immunomodulator, in the treatment of Crohn's disease. Aliment Pharmacol Ther 2016;44:1102-1113.

33. Ananthakrishnan A, Sakuraba A, Barnes EL, et al. The benefit of combination therapy depends on disease phenotype and duration in Crohn's disease. Aliment Pharmacol Ther 2017;46:162-168.

34. Khanna R, Bressler B, Levesque BG, et al; REACT Study Investigators. Early combined immunosuppression for the management of Crohn's disease (REACT): a cluster randomised controlled trial. Lancet 2015;386:1825-1834.

35. Hoekman DR, Stibbe JA, Baert FJ, et al. Long-term outcome of early combined immunosuppression versus conventional management in newly diagnosed Crohn's disease. J Crohns Colitis 2018;12:517-524.

36. Jones JL, Kaplan GG, Peyrin-Biroulet L, et al. Effects of concomitant immunomodulator therapy on efficacy and safety of anti-tumor necrosis factor therapy for Crohn's disease: a meta-analysis of placebo-controlled trials. Clin Gastroenterol Hepatol 2015;13:22332240.e1-e2.

37. Singh S, Heien HC, Sangaralingham LR, et al. Comparative effectiveness and safety of anti-tumor necrosis factor agents in biologic-naive patients with Crohn's disease. Clin Gastroenterol Hepatol 2016;14:1120-1129.

38. Peyrin-Biroulet L, Salleron J, Filippi J, et al. Anti-TNF monotherapy for Crohn's disease: a 13-year multicentre experience. J Crohns Colitis 2016;10:516-524.

39. Targownik LE, Benchimol EI, Bernstein CN, et al. Upfront combination therapy, compared with monotherapy, for patients not previously treated with a biologic agent associates with reduced risk of inflammatory bowel disease-related complications in a population-based cohort study. Clin Gastroenterol Hepatol 2019;17:1788-1798.

40. Chen C, Hartzema AG, Xiao H, et al. Real-world pattern of biologic use in patients with inflammatory bowel disease: treatment persistence, switching, and importance of concurrent immunosuppressive therapy. Inflamm Bowel Dis 2019;8:1417-1427.

41. Allegretti JR, Barnes EL, Stevens B, et al. Predictors of clinical response and remission at 1 year among a multicenter cohort of patients with inflammatory bowel disease treated with vedolizumab. Dig Dis Sci 2017;62:1590-1596.

42. Colombel JF, Loftus EV, Siegel CA, et al. Sa1270 efficacy of vedolizumab with concomitant corticosteroid or immunomodulator use in patients with Crohn's disease from GEMINI 2. Gastroenterology 2015;148:S-277.

43. Colombel JF, Loftus EV, Siegel CA, et al. Sa1271 efficacy of vedolizumab with concomitant corticosteroid or immunomodulator use in patients with ulcerative colitis from GEMINI 1. Gastroenterology 2015;148:S277-S278. 
44. Rosario M, Dirks NL, Milch C, et al. A review of the clinical pharmacokinetics, pharmacodynamics, and immunogenicity of vedolizumab. Clin Pharmacokinet 2017;56:1287-1301.

45. Hu A, Kotze PG, Burgevin A, et al. Combination therapy does not improve rate of clinical or endoscopic remission in patients with inflammatory bowel diseases treated with vedolizumab or ustekinumab. Clin Gastroenterol Hepatol 2020 Jul 12 [Online ahead of print]. doi: 10.1016/j.cgh.2020.07.012

46. Hanauer SB, Sandborn WJ, Feagan BG, et al. IM-UNITI: Threeyear efficacy, safety, and immunogenicity of ustekinumab treatment of Crohn's disease. J Crohns Colitis 2020;14:23-32.

47. Wils P, Bouhnik Y, Michetti P, et al; Groupe d'Etude Thérapeutique des Affections Inflammatoires du Tube Digestif. Subcutaneous ustekinumab provides clinical benefit for two-thirds of patients with Crohn's disease refractory to anti-tumor necrosis factor agents. Clin Gastroenterol Hepatol 2016;14:242-250.e1-e2.

48. Battat R, Kopylov U, Bessissow T, et al. Association between ustekinumab trough concentrations and clinical, biomarker, and endoscopic outcomes in patients with Crohn's disease. Clin Gastroenterol Hepatol 2017;15:1427-1434.

49. Adedokun OJ, Xu Z, Gasink C, et al. Pharmacokinetics and exposure response relationships of ustekinumab in patients with Crohn's disease. Gastroenterology 2018;154:1660-1671.

50. Reinisch W, Sandborn WJ, Hommes DW, et al. Adalimumab for induction of clinical remission in moderately to severely active ulcerative colitis: results of a randomised controlled trial. Gut 2011;60:780-787.

51. Sandborn WJ, Feagan BG, Marano C, et al; PURSUIT-Maintenance Study Group. Subcutaneous golimumab maintains clinical response in patients with moderate-to-severe ulcerative colitis. Gastroenterology 2014;146:96-109.

52. Sandborn WJ, van Assche G, Reinisch W, et al. Adalimumab induces and maintains clinical remission in patients with moderate-tosevere ulcerative colitis. Gastroenterology 2012;142:257-265.e1-e3.

53. Kornbluth A, Sachar DB; Practice Parameters Committee of the American College of Gastroenterology. Ulcerative colitis practice guidelines in adults: American College Of Gastroenterology, Practice Parameters Committee. Am J Gastroenterol 2010;105:501-523.

54. Harbord M, Eliakim R, Bettenworth D, et al. Third European evidence-based consensus on diagnosis and management of ulcerative colitis. Part 2: current management. J Crohns Colitis 2017;11:769-784.

55. Rutgeerts P, Sandborn WJ, Feagan BG, et al. Infliximab for induction and maintenance therapy for ulcerative colitis. $N \mathrm{Engl} \mathrm{J}$ Med 2005;353:2462-2476.

56. Christophorou D, Funakoshi N, Duny Y, et al. Systematic review with meta-analysis: infliximab and immunosuppressant therapy vs. infliximab alone for active ulcerative colitis. Aliment Pharmacol Ther 2015;41:603-612.

57. Armuzzi A, Pugliese D, Danese S, et al. Long-term combination therapy with infliximab plus azathioprine predicts sustained steroid-free clinical benefit in steroid-dependent ulcerative colitis. Inflamm Bowel Dis 2014;20:1368-1374.

58. Filippi J, Laharie D, Michiels C, et al. Efficacy of sustained combination therapy for at least 6 months with thiopurines and infliximab in patients with ulcerative colitis in clinical remission: a retrospective multicenter French experience. J Crohns Colitis 2015;9:252-258.

59. Flamant M, Paul S, Roblin X. Golimumab for the treatment of ulcerative colitis. Expert Opin Biol Ther 2017;17:879-886.

60. Lichtenstein GR, Feagan BG, Cohen RD, et al. Serious infection and mortality in patients with Crohn's disease: more than 5 years of follow-up in the TREAT ${ }^{\text {mo }}$ registry. Am J Gastroenterol 2012;107:1409-1422.

61. Beaugerie L, Brousse N, Bouvier AM, et al; CESAME Study Group.
Lymphoproliferative disorders in patients receiving thiopurines for inflammatory bowel disease: a prospective observational cohort study. Lancet 2009;374:1617-1625.

62. Beaugerie L. Lymphoma: the bête noire of the long-term use of thiopurines in adult and elderly patients with inflammatory bowel disease. Gastroenterology 2013;145:927-930.

63. Herrinton LJ, Liu L, Weng X, Lewis JD, Hutfless S, Allison JE. Role of thiopurine and anti-TNF therapy in lymphoma in inflammatory bowel disease. Am J Gastroenterol 2011;106:2146-2153.

64. Burmester GR, Panaccione R, Gordon KB, McIlraith MJ, Lacerda AP. Adalimumab: long-term safety in 23458 patients from global clinical trials in rheumatoid arthritis, juvenile idiopathic arthritis, ankylosing spondylitis, psoriatic arthritis, psoriasis and Crohn's disease. Ann Rheum Dis 2013;72:517-524.

65. Dulai PS, Siegel CA, Peyrin-Biroulet L. Anti-tumor necrosis factor- $\alpha$ monotherapy versus combination therapy with an immunomodulator in IBD. Gastroenterol Clin North Am 2014;43:441-456.

66. Dulai PS, Siegel CA, Colombel JF, Sandborn WJ, PeyrinBiroulet L. Systematic review: monotherapy with antitumour necrosis factor alpha agents versus combination therapy with an immunosuppressive for IBD. Gut 2014;63:1843-1153.

67. Lemaitre M, Kirchgesner J, Rudnichi A, et al. Association between use of thiopurines or tumor necrosis factor antagonists alone or in combination and risk of lymphoma in patients with inflammatory bowel disease. JAMA 2017;318:1679-1686.

68. Lichtenstein GR, Hanauer SB, Sandborn WJ; Practice Parameters Committee of American College of Gastroenterology. Management of Crohn's disease in adults. Am J Gastroenterol 2009;104:465-483; quiz 464, 484.

69. Osterman MT, Sandborn WJ, Colombel JF, et al. Increased risk of malignancy with adalimumab combination therapy, compared with monotherapy, for Crohn's disease. Gastroenterology 2014;146:941-949.

70. Shale M, Kanfer E, Panaccione R, Ghosh S. Hepatosplenic T cell lymphoma in inflammatory bowel disease. Gut 2008;57:1639-1641.

71. Mackey AC, Green L, Leptak C, Avigan M. Hepatosplenic T cell lymphoma associated with infliximab use in young patients treated for inflammatory bowel disease: update. J Pediatr Gastroenterol Nutr 2009;48:386-388.

72. Toruner M, Loftus EV Jr, Harmsen WS, et al. Risk factors for opportunistic infections in patients with inflammatory bowel disease. Gastroenterology 2008;134:929-936.

73. Siegel CA, Marden SM, Persing SM, Larson RJ, Sands BE. Risk of lymphoma associated with combination anti-tumor necrosis factor and immunomodulator therapy for the treatment of Crohn's disease: a meta-analysis. Clin Gastroenterol Hepatol 2009;7:874-881.

74. Duchesne C, Faure P, Kohler F, et al; CREGG (Club de Reflexion des cabinets et Groupes d'Hépato-Gastroentérologie). Management of inflammatory bowel disease in France: a nationwide survey among private gastroenterologists. Dig Liver Dis 2014;46:675-681.

75. Long MD, Herfarth HH, Pipkin CA, Porter CQ, Sandler RS, Kappelman MD. Increased risk for non-melanoma skin cancer in patients with inflammatory bowel disease. Clin Gastroenterol Hepatol 2010;8:268-274.

76. Singh H, Nugent Z, Demers AA, Bernstein CN. Increased risk of nonmelanoma skin cancers among individuals with inflammatory bowel disease. Gastroenterology 2011;141:1612-1620.

77. Long MD, Martin CF, Pipkin CA, Herfarth HH, Sandler RS, Kappelman MD. Risk of melanoma and nonmelanoma skin cancer among patients with inflammatory bowel disease. Gastroenterology 2012;143:390-399.

78. Peyrin-Biroulet L, Khosrotehrani K, Carrat F, et al; Cesame Study Group. Increased risk for nonmelanoma skin cancers in patients who receive thiopurines for inflammatory bowel disease. Gastroenterology 2011;141:1621-1628.e1-e5. 
79. Sazonovs A, Kennedy NA, Moutsianas L, et al; PANTS Consortium. HLA-DQA $1^{\star} 05$ carriage associated with development of anti-drug antibodies to infliximab and adalimumab in patients with Crohn's disease. Gastroenterology 2020;158:189-199.

80. Feagan BG, Sandborn WJ, Gasink C, et al; UNITI-IM-UNITI Study Group. Ustekinumab as induction and maintenance therapy for Crohn's disease. N Engl J Med 2016;375:1946-1960.

81. Roblin X, Serre-Debeauvais F, Phelip JM, Bessard G, Bonaz B. Drug interaction between infliximab and azathioprine in patients with Crohn's disease. Aliment Pharmacol Ther 2003;18:917-925.

82. Dubinsky MC, Lamothe S, Yang HY, et al. Pharmacogenomics and metabolite measurement for 6-mercaptopurine therapy in inflammatory bowel disease. Gastroenterology 2000;118:705-713.

83. Wong DR, Pierik M, Seinen ML, et al. The pharmacokinetic effect of adalimumab on thiopurine metabolism in Crohn's disease patients. J Crohns Colitis 2014;8:120-128.

84. Karmiris K, Paintaud G, Noman M, et al. Influence of trough serum levels and immunogenicity on long-term outcome of adalimumab therapy in Crohn's disease. Gastroenterology 2009;137:1628-1640.

85. Hanauer SB, Sandborn WJ, Rutgeerts P, et al. Human anti-tumor necrosis factor monoclonal antibody (adalimumab) in Crohn's disease: the CLASSIC-I trial. Gastroenterology 2006;130:323-333; quiz 591.

86. Sandborn WJ, Hanauer SB, Rutgeerts P, et al. Adalimumab for maintenance treatment of Crohn's disease: results of the CLASSIC II trial. Gut 2007;56:1232-1239.

87. Chiu YL, Rubin DT, Vermeire S, et al. Serum adalimumab concentration and clinical remission in patients with Crohn's disease. Inflamm Bowel Dis 2013;19:1112-1122.

88. Fernandes SR, Bernardo S, Simões C, et al. Proactive infliximab drug monitoring is superior to conventional management in inflammatory bowel disease. Inflamm Bowel Dis 2020;26:263-270.

89. Scott FI, Vajravelu RK, Bewtra M, et al. The benefit-to-risk balance of combining infliximab with azathioprine varies with age: a Markov model. Clin Gastroenterol Hepatol 2015;13:302-309.

90. Reinisch W, Colombel JF, Sandborn WJ, et al. Factors associated with short- and long-term outcomes of therapy for Crohn's disease. Clin Gastroenterol Hepatol 2015;13:539-547.

91. Oussalah A, Chevaux JB, Fay R, Sandborn WJ, Bigard MA, PeyrinBiroulet L. Predictors of infliximab failure after azathioprine withdrawal in Crohn's disease treated with combination therapy. Am J Gastroenterol 2010;105:1142-1149.

92. Sokol H, Seksik P, Carrat F, et al. Usefulness of co-treatment with immunomodulators in patients with inflammatory bowel disease treated with scheduled infliximab maintenance therapy. Gut 2010;59:1363-1368.

93. Yarur AJ, Kubiliun MJ, Czul F, et al. Concentrations of 6-thioguanine nucleotide correlate with trough levels of infliximab in patients with inflammatory bowel disease on combination therapy. Clin Gastroenterol Hepatol 2015;13:1118-1124.e3.

94. Mogensen DV, Brynskov J, Ainsworth MA, Nersting J, Schmiegelow K, Steenholdt C. A role for thiopurine metabolites in the synergism between thiopurines and infliximab in inflammatory bowel disease. J Crohns Colitis 2018;12:298-305.

95. de Boer NKH, Peyrin-Biroulet L, Jharap B, et al. Thiopurines in inflammatory bowel disease: new findings and perspectives. J Crohns Colitis 2018;12:610-620.

96. Louis E, Mary JY, Vernier-Massouille G, et al; Groupe D'etudes Thérapeutiques Des Affections Inflammatoires Digestives. Maintenance of remission among patients with Crohn's disease on antimetabolite therapy after infliximab therapy is stopped. Gastroenterology 2012;142:63-70.

97. Reenaers C, Mary JY, Nachury M, et al; Groupe d'Etude Therapeutique des Affections Inflammatoires du tube Digestif. Outcomes 7 years after infliximab withdrawal for patients with Crohn's disease in sustained remission. Clin Gastroenterol Hepatol 2018; 16:234-243.

98. Torres J, Boyapati RK, Kennedy NA, Louis E, Colombel JF, Satsangi J. Systematic review of effects of withdrawal of immunomodulators or biologic agents from patients with inflammatory bowel disease. Gastroenterology 2015;149:1716-1730.

99. Sands BE, Anderson FH, Bernstein $\mathrm{CN}$, et al. Infliximab maintenance therapy for fistulizing Crohn's disease. $N$ Engl J Med 2004;350:876-885.

100. Sorrentino D, Nash P, Viladomiu M, Hontecillas R, BassaganyaRiera J. Stopping anti-TNF agents in patients with Crohn's disease in remission: is it a feasible long-term strategy? Inflamm Bowel Dis 2014;20:757-766.

101. Ampuero J, Rojas-Feria M, Castro-Fernández M, MillánLorenzo M, Guerrero-Jiménez P, Romero-Gómez M. Remission maintained by monotherapy after biological + immunosuppressive combination for Crohn's disease in clinical practice. J Gastroenterol Hepatol 2016;31:112-118.

102. Henriksen M, Jahnsen J, Lygren I, et al; IBSEN Study Group. C-reactive protein: a predictive factor and marker of inflammation in inflammatory bowel disease. Results from a prospective population-based study. Gut 2008;57:1518-1523.

103. Pittet V, Froehlich F, Maillard MH, et al; EPACT-II Update Panellists. When do we dare to stop biological or immunomodulatory therapy for Crohn's disease? Results of a multidisciplinary European expert panel. J Crohns Colitis 2013;7:820-826.

104. Louis E, Belaiche J, Reenaers C. Tailoring the treatment to the individual in Crohn's disease. Therap Adv Gastroenterol 2009;2:239-244. 